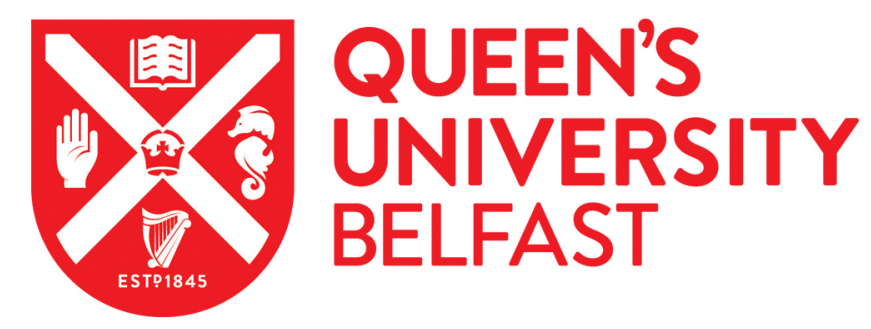

\title{
Radiocarbon Ecology of the Land Snail Helix Melanostoma in Northeastern Libya
}

Hill, E. A., Reimer, P. J., Hunt, C. O., Prendergast, A. L., \& Barker, G. W. (2017). Radiocarbon Ecology of the Land Snail Helix Melanostoma in Northeastern Libya. Radiocarbon, 59(Special Issue 5), 1521-1542. https://doi.org/10.1017/RDC.2017.49

\section{Published in:}

Radiocarbon

\section{Document Version:}

Peer reviewed version

Queen's University Belfast - Research Portal:

Link to publication record in Queen's University Belfast Research Portal

\section{Publisher rights}

(C) 2017 by the Arizona Board of Regents on behalf of the University of Arizona.

This work is made available online in accordance with the publisher's policies. Please refer to any applicable terms of use of the publisher.

\section{General rights}

Copyright for the publications made accessible via the Queen's University Belfast Research Portal is retained by the author(s) and / or other copyright owners and it is a condition of accessing these publications that users recognise and abide by the legal requirements associated with these rights.

Take down policy

The Research Portal is Queen's institutional repository that provides access to Queen's research output. Every effort has been made to ensure that content in the Research Portal does not infringe any person's rights, or applicable UK laws. If you discover content in the Research Portal that you believe breaches copyright or violates any law, please contact openaccess@qub.ac.uk. 


\section{RADIOCARBON}

\section{圂囯 CAMBRIDGE



\section{Radiocarbon Ecology of the terrestrial mollusc Helix melanostoma in Northeast Libya.}

\begin{tabular}{|r|l|}
\hline Journal: & Radiocarbon \\
\hline Manuscript ID & RDC-CONF-2016-0116.R2 \\
\hline Manuscript Type: & 2016 Radiocarbon and Archaeology Conference Paper \\
\hline Complete List of Authors: & $\begin{array}{l}\text { Hill, Evan; Queens University Belfast, Natural and Built Environment } \\
\text { Reimer, Paula; Queens University Belfast, Natural and Built Environment } \\
\text { Hunt, Christopher; Liverpool John Moores University, School of Natural } \\
\text { Sciences and Psychology } \\
\text { Prendergast, Amy; University of Melbourne, School of Geography } \\
\text { Barker, Graeme; University of Cambridge, McDonald Institute for } \\
\text { Archaeological Research }\end{array}$ \\
\hline Keywords: & $\begin{array}{l}\text { Terrestrial Molluscs, Radiocarbon dating, Ecology, North Africa, Stable } \\
\text { isotopes }\end{array}$ \\
\hline
\end{tabular}

SCHOLARONE ${ }^{\text {m }}$

Manuscripts 
Title: Radiocarbon Ecology of the land snail Helix melanostoma in Northeast Libya.

Authors: Hill E.A., Reimer, P.J., Hunt, C.O., Prendergast, A.L., Barker, G.W.

\title{
Keywords
}

Land Snails; Terrestrial Molluscs; Radiocarbon; Ecology; North Africa; Dating; Isotopes

\begin{abstract}
Terrestrial gastropods are problematical for radiocarbon because they tend to incorporate carbon from ancient sources as a result of their dietary behaviour. The radiocarbon ecology of the pulmonate land snail, Helix melanostoma in Cyrenaica, north eastern Libya, was investigated as part of a wider study on the potential of using terrestrial mollusc shell for radiocarbon dating of archaeological deposits. $H$. melanostoma was selected out of the species available in the region as it has the most predictable radiocarbon ecology and also had a ubiquitous presence within the local archaeology. The ecological observations indicate that $\mathrm{H}$. melanostoma has a very homogenous radiocarbon ecology with consistent variations in $\mathrm{F}^{14} \mathrm{C}$ across sample sites controlled by availability of dietary vegetation. The majority of dated specimens from non-urbanized sample locations have only a small old carbon effect, weighted mean of $476 \pm 48{ }^{14} \mathrm{C}$ yrs, with between $1-9 \%$ of dietary $\mathrm{F}^{14} \mathrm{C}$ from non-organic carbonate sources. Observed instabilities in the radiocarbon ecology can all be attributed to the results of intense human activity not present before the Roman Period. Therefore, $H$. melanostoma and species with similar ecological behaviour are suitable for ${ }^{14} \mathrm{C}$ dating of archaeological and geological deposits with the use of a suitable offset.
\end{abstract}




\section{Introduction}

Land snail shells are widely distributed in Quaternary deposits and frequent on archaeological sites (Prendergast \& Stevens 2014). Initial investigations (Goodfriend and Hood, 1983; Goodfriend 1987; Pigati et al., 2010; Hill 2015; Hunt et al., 2015) suggest that in suitable circumstances it is amenable to radiocarbon dating; opening up the possibility of extending radiocarbon chronologies into sedimentary facies containing no other source of biotic carbon. For instance, in calcareous oxidised sediments in semi-arid and arid environments, land snail shell is often well preserved but plant macrofossils and wood are not always available and bone collagen is often not preserved (e.g. Hunt et al., 1992; Anketell et al., 1995; Hunt \& Garrard, 2013). Land-snail shells may offer the only possibility for radiocarbon dating such sites.

Previous studies (e.g. Goodfriend 1987; Romanellio et al., 2008; Pigati et al 2010; Hill 2015) have shown that the ecological pathways and uptake mechanisms undergone by ${ }^{14} \mathrm{C}$ as it is incorporated into the shell of land snails are not straightforward. Some species are detritivores, others graze on algae encrusting carbonate rocks. In both, old carbon may be consumed and incorporated into shell, causing a well-documented impact on radiocarbon values, and the shells to have radiocarbon age values significantly older than their actual age. It is also possible, although thus far unproven, that some taxa may fractionate carbon in their metabolic processes (McConnaughy and Gillikin 2008). An understanding of the radiocarbon ecology at a generic, if not specific, level is therefore required before a species can be used for dating.

This paper presents the radiocarbon ecology of the Helicid land snail Helix melanostoma (Draparnaud, 1801) in Northeast Libya. The work was undertaken to provide a baseline for radiocarbon dating of this species in Quaternary archaeological deposits throughout the Mediterranean and in particular in the Haua Fteah archaeological site lying approximately 1 $\mathrm{km}$ south of the Mediterranean coast in northeast Libya, some $7.5 \mathrm{~km}$ east of Susa at E22 ${ }^{\circ}$ 03'06" N32 ${ }^{\circ}$ 54' 01" (Barker et al., 2007, 2008, 2009, 2010, 2012; Rabett et al., 2012; Farr et al., 2014.)

\section{Background: The radiocarbon ecology of land molluscs}

The mechanisms by which ${ }^{14} \mathrm{C}$ is incorporated into the shells of land snails are complex and interconnected (Figure 1). Three key pathways can be clearly defined by which carbon moves through the metabolism of a snail: respiration, diet, and hydration. Of these, diet accounts for the vast majority of carbon laid down in the shell (e.g. Stott 2002; McConnaughy and Gillikin 2008, Xu et al 2011). Dietary carbon can be from living vegetation, which will be broadly in radiocarbon equilibrium with atmospheric levels. Dietary carbon is also likely to include ancient carbon from a variety of sources, as mentioned above. Similarly, hydration may include precipitation water condensed from the atmosphere, which will be in equilibrium with atmospheric ${ }^{14} \mathrm{C}$ values and also water that has been in contact with, and dissolved, ancient carbon; including atmospheric mineral dust, limestone and dead organic matter in soils.

The role of $\delta^{13} \mathrm{C}$ in interpreting land snail ecology has been widely explored. The relationship between this isotope and radiocarbon dating land snails has long been an integral element in assessing the impact of 'old carbon'. More recent detailed investigations of the ${ }^{14} \mathrm{C}$ dating of land snails (e.g. Pigati et al., 2010) have begun to demonstrate that while $\delta^{13} \mathrm{C}$ is 
important for fractionation correction in the measurement of ${ }^{14} \mathrm{C}$ values it is not particularly useful in determining 'old carbon' impact (e.g. Romaniello et al., 2008;Xu et al., 2011).

Figure 1. Model for the radiocarbon ecology of land snails after Goodfriend, (1987) with modifications based on Stott, (2002) and Pigati et al., (2004, 2010)

Understanding the relationship between the three isotopes of carbon within the biochemistry of the land snail are both integral to understanding why $\delta^{13} \mathrm{C}$ is not as important for identifying old carbon and also why a clear understanding of the life processes of the snail in acquiring carbon are vital to this point (Figure 1). Research has shown that atmospheric sources of carbon tend to have proportionally less impact on the processes involved in shell formation in land snails in comparison to dietary sources (e.g. McConnaughy and Gillikin, 2009 and references therein). Thus, it has been argued, based on the biological principles underlying the carbon cycle in molluscs, that $\mathrm{CO}_{2}$ derived from respiration does not, in normal circumstances, have a significant impact on the ${ }^{14} \mathrm{C} /{ }^{12} \mathrm{C}$ ratio of landsnails (McConnaughy \& Gillikin 2009).

The influence of dissolved inorganic carbonate (DIC) in water is understood only for a very few species e.g. Succinidae, which are generally atypical of land snails (Pigati et al., 2004, 2010). Inference based on biochemistry of similar organisms does suggest that DIC should not in normal circumstances account for a significant portion of land snail shell carbonate (McConnaughy \& Gillikin 2009).

The ingestion of old carbon from various sources has been the subject of a limited number of studies (e.g. De Jorge and Haeser, 1968; Tamers, 1970; Magaritz et al., 1981; Goodfriend and Hood, 1983; Goodfriend, 1987; Goodfriend and Ellis, 2002; Stott, 2002; Pigati et al., 2004; Balakrishnan and Yapp, 2004; Baldini et al., 2007; Yanes et al., 2008; Romaniello et al., 2008; Pigati et al., 2010; Xu et al., 2010; Xu et al., 2011; Rakovan et al., 2013). Review of these papers demonstrates that there is little replication or overlap in species analysed or geographical regions sampled. Only in North America is there any consequential overlap; for Europe, North Africa and elsewhere there is no significant replication. A number of studies examining the use of terrestrial shell carbonate for ${ }^{14} \mathrm{C}$ dating have also indicated, using radiocarbon analysis, that old carbon can account for as much as $30-40 \%$ of carbonate in a shell (e.g. Goodfriend and Stipp 1983; Goodfriend and Ellis 2002 Pigati et al 2004, 2010). However, the quantities ingested appear to hinge on a wide variety of influencing factors in local environments and are taxon-dependent.

The mass balance approach pioneered by Goodfriend and Hood (1983) for modelling the isotopic fractions of carbon in terrestrial land snail shells has been heavily utilized. It has been found to be problematic because it is not possible to separate the sources of ${ }^{14} \mathrm{C}$ (Figure 1 ) to the degree required to sufficiently isolate the component parts of the diet for the mass balance equation to be properly calculated (e.g. Romanellio et al., 2008; Pigati et al., 2010; Xu et al., 2011; Hill 2015). These issues further reinforce the need to build a clear understanding of the modern ecology, as well as the physiology of any species, before the radiocarbon ages can be defined with confidence. This is particularly the case for the current work in Cyrenaica because previous studies of radiocarbon ecology in the Mediterranean (e.g. Goodfriend, 1987, Romanellio et al., 2008) have not examined terrestrial gastropods common in this region.

\section{Methods and Materials}




\section{Study Region}

Sampling for modern snail shells and vegetation took place in northeast Libya (Figure 2). Here the Gebel Akhdar massif rises to over $800 \mathrm{~m}$ in three great escarpments. The region is an inverted Mesozoic-Tertiary basin, geologically characterised by thick limestones and thin calcareous mudstones (El Hawat \& Abdelsamad, 2004). Rainfall on the Gebel Akhdar is significantly higher than elsewhere along the northeast African littoral (Sen \& Eljadid 1999) and the region is a 'habitat island' of Mediterranean vegetation among the generally arid lowlands to the west, south and east. The region bordering the coastal plain with richer soils and less limestone outcropping has noticeably more lush vegetation cover compared with the rising slopes of the Gebel Akhdar, which are heavily grazed. The slope of the first escarpment of the Gebel Akhdar is dominated by juniper scrub with large limestone outcroppings and shallow soils. The higher regions of the Gebel were originally covered in Cupressus-Oak forests but are now largely cleared for agriculture. The southern slopes are in rain shadow and largely covered with steppe, grading southward into true desert (Barker 2007; Hegazy et al., 2011

\section{Ecological Patterning of $\mathrm{H}$. melanostoma}

Very little information is available on the ecology and distribution of land snails in the Gebel Akhdar. The most informative publication (Brandt, 1959), although primarily taxonomic, provides some very short ecological descriptions of the family Helicidae. All Helicidae in the region are xerophytic to varying degrees and the species are found in habitats ranging from Mediterranean woodland to semi-desert.

In the study area, our surveys and conversations with local specialists suggest, that $H$. melanostoma spends most of the year aestivating in shallow, damp shaded soils beneath scrub or small trees such as Ceratonia siliqua, Pistacia lentiscus and Rhus tripartita in areas of limestone pavement, scrub on slopes with shallow soils, and scrub-forest on deep soils (Hill 2010). It is inferred that low-lying, mostly evergreen, vegetation forms the local primary food source of $H$. melanostoma. These findings were further reinforced by the stable isotope study (Prendergast et al., 2014, 2015) which showed that $\delta^{13} \mathrm{C}$ in $\mathrm{H}$. melanostoma shell carbonate was primarily a function of the animals diet which is the local available vegetation. Therefore, changes in shell $\delta^{13} \mathrm{C}$ can be used to detect changes in vegetation composition, particularly in relation to the abundance of C3 and C4 vegetation (Prendergast et al., 2014). Our environmental observations concerning this species broadly support ecological findings from southern France (e.g. Kerney et al., 1983; Pfleger, 1984) for $H$. melanostoma.

\section{Sample Sites and Methodology}

An initial radiocarbon evaluation of a number of surface collected mollusc shells, presumed to be recently dead, carried out in 2010, of the four archaeologically-important land snail species known to be abundant in the Haua Fteah archaeological site is shown in Table 1. This evaluation suggests that Helix melanostoma has less of an age offset, and less variability than Trochoidea cretica or Sphincterochila spp., the other ubiquitous species present both in the modern landscape and in the archaeological assemblages and sediments in the Haua Fteah. Rumina cf. decollata was ruled out based on ecological knowledge of diet and because no modern living specimens could be found in follow-up sampling. Therefore, 
based on its ubiquitous presence in archaeological sediments, and modern ages in this study H. melanostoma was selected for intensive work. The outlying sample, UBA 15321, appears to be archaeological material that was present on the landscape at the point of collection, based on comparisons of ages of material from within the Haua Sequence (Hill, 2015) reinforcing the importance of live collected specimens for studies like this.

\begin{tabular}{|c|c|c|c|c|c|}
\hline Species & UBA No. & $\mathrm{F}^{14} \mathrm{C}$ & \pm & ${ }^{14} \mathrm{C}$ Age & \pm \\
\hline H. melanostoma & 15321 & 0.274 & 0.0012 & 10395 & 36 \\
\hline H. melanostoma & 15322 & 1.0246 & 0.0034 & mod & \\
\hline H. melanostoma & 15323 & 1.1279 & 0.0035 & mod & \\
\hline Rumina cf. decollata & 15324 & 0.8904 & 0.0029 & 932 & 26 \\
\hline Rumina cf. decollata & 15325 & 0.7912 & 0.0026 & 1882 & 27 \\
\hline Rumina cf. decollata & 15326 & 0.8709 & 0.0029 & 1110 & 26 \\
\hline Trochoidea cretica & 15327 & 0.91 & 0.0029 & 758 & 26 \\
\hline Trochoidea cretica & 15329 & 0.7857 & 0.0026 & 1938 & 27 \\
\hline Sphincterochila spp. & 15333 & 0.9923 & 0.0044 & 62 & 35 \\
\hline Sphincterochila spp. & 15334 & 0.8151 & 0.0037 & 1642 & 37 \\
\hline Sphincterochila spp. & 15335 & 0.8866 & 0.004 & 967 & 36 \\
\hline
\end{tabular}

Table 1: Results of pilot study evaluating $\mathrm{F}^{14} \mathrm{C}$ variation of land snails in North Eastern Libya at site CPPO7 1587. ${ }^{14} \mathrm{C}$ ages are not rounded here to avoid introduction of errors in calculations.

The sampling of live collected modern specimens was carried out during 2010 and 2012 field seasons (Hill 2010; Barker et al., 2012; Rabett et al., 2012; Prendergast et al., 2015). The sampling strategy was designed to encompass the widest possible range of modern environments within the study area but focused on five key locations given the constraints of time and security (Figure 2; Table 2). Site sample identifications for sites have been shortened in all tables and figures as follows: HF12_Eco refers to sites around the Haua Fteah; AP12 to Apollonia; RH12 to the Project Resthouse, Shahat; MH12 to Gebel Akhdar massif sample sites.

At these localities transect sampling found live aestivated specimens in leaf litter and soil beneath vegetation and active molluscs on vegetation after very rare rainfall events. Ethnographic observations suggest that all of these sites are extremely heavily grazed by domesticated animals, mostly goats and sheep and vegetation levels are consequently lower than would be expected in habitats grazed by native animals. It is also likely that a number of sites were impacted by the relatively intense anthropogenic activity on the Gebel, near Shahat, Susa and Albayda including mass building work, cement works and atmospheric pollution.

Figure 2. Sample locations in Cyrenaica for this study. $A=$ Haua Fteah (HF_Eco), $B=$ Wadi Chartopolis (MH12-6), C = Gebel Akhdar 1 (MH12-9), $\mathrm{D}=$ Gebel Akhdar 2(MH12-10), $\mathrm{E}=$ Gebel Akhdar 3(MH12-11), F = Shahat project Resthouse (RH12), G = Apollonia (AP12). 


\begin{tabular}{|c|c|c|c|c|c|c|c|c|c|c|c|}
\hline Site & Location & $\begin{array}{l}\text { Site } \\
\text { Code }\end{array}$ & 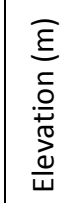 & $\begin{array}{c}\text { Dominant } \\
\text { vegetation }\end{array}$ & $\begin{array}{c}\text { est. total } \\
\text { vegetation } \\
\%\end{array}$ & $\begin{array}{c}\text { est. } \\
\text { arboreal } \\
\%\end{array}$ & $\begin{array}{c}\text { Sampled } \\
\text { vegetation } \\
\text { taxon }\end{array}$ &  & 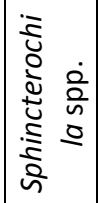 & 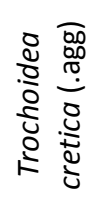 & Date \\
\hline \multirow[t]{5}{*}{ Haua Fteah } & $\begin{array}{c}32^{\circ} 54.017 \\
22^{\circ} 3.011 \\
\end{array}$ & $\begin{array}{c}\mathrm{HF} \\
\text { Eco02 }\end{array}$ & 75 & $\begin{array}{c}\text { Scrub with some } \\
\text { herbaceous } \\
\text { vegetation: } P L, \\
\text { CS, } P\end{array}$ & 70 & 50 & $\begin{array}{c}\text { Ceratonia } \\
\text { siliqua }\end{array}$ & 5 & 0 & 3 & $\begin{array}{l}\text { April } \\
2010\end{array}$ \\
\hline & & $\begin{array}{c}\mathrm{HF} \\
\text { Eco03 }\end{array}$ & 70 & $\begin{array}{c}\text { Dense scrub with } \\
\text { herbaceous } \\
\text { vegetation: } P L, \\
P H, J O, R T, C S, P\end{array}$ & 75 & 60 & \begin{tabular}{|l|} 
Juniperus \\
oxycedrus
\end{tabular} & 3 & 0 & 2 & $\begin{array}{l}\text { April } \\
2010 \\
\end{array}$ \\
\hline & & $\begin{array}{c}\mathrm{HF} \\
\text { Eco04 }\end{array}$ & 66 & $\begin{array}{c}\text { Scrub woodland } \\
\text { on limestone: } \\
\text { CS, JO }\end{array}$ & 90 & 70 & $\begin{array}{l}\text { Juniperus } \\
\text { oxycedrus }\end{array}$ & 1 & 2 & 3 & $\begin{array}{l}\text { April } \\
2010 \\
\end{array}$ \\
\hline & & $\begin{array}{c}\mathrm{HF} \\
\mathrm{Eco0} 0\end{array}$ & 50 & $\begin{array}{c}\text { Scrub woodland } \\
\text { on limestone } \\
\text { with light } \\
\text { herbaceous } \\
\text { vegetation: JO, } \\
R T, C S, P, P H\end{array}$ & 80 & 60 & $\begin{array}{l}\text { Juniperus } \\
\text { oxycedrus }\end{array}$ & 2 & 1 & 4 & $\begin{array}{l}\text { April } \\
2010\end{array}$ \\
\hline & & $\begin{array}{c}\mathrm{HF} \\
\text { Eco06 }\end{array}$ & 49 & $\begin{array}{c}\text { Scrub woodland } \\
\text { with herbaceous } \\
\text { vegetation: CS, } \\
\text { JO, RT, SS, PL, P, } \\
P H\end{array}$ & 90 & 60 & $\begin{array}{c}\text { Ceratonia } \\
\text { siliqua }\end{array}$ & 8 & 2 & 9 & $\begin{array}{l}\text { April } \\
2010\end{array}$ \\
\hline $\begin{array}{c}\text { Apollonia } \\
\text { (Susa) }\end{array}$ & $\begin{array}{l}32^{\circ} 54.176 \\
21^{\circ} 58.524\end{array}$ & AP12 & 5 & $\begin{array}{c}\text { Sparse coastal } \\
\text { Scrubland: } P L, \\
\text { AS }\end{array}$ & 20 & 5 & $\begin{array}{c}\text { Artemisia } \\
\text { sp. }\end{array}$ & 5 & 4 & 10 & $\begin{array}{l}\text { May } \\
2012\end{array}$ \\
\hline $\begin{array}{l}\text { Resthouse } \\
\text { (Shahat) }\end{array}$ & $\begin{array}{l}32^{\circ} 49.579 \\
21^{\circ} 51.730\end{array}$ & RH12 & 590 & $\begin{array}{c}\text { Urbanized } \\
\text { Woodland:CS }\end{array}$ & 95 & 30 & $\begin{array}{c}\text { Ceratonia } \\
\text { siliqua }\end{array}$ & 4 & 0 & 12 & $\begin{array}{l}\text { May } \\
2012\end{array}$ \\
\hline $\begin{array}{c}\text { Wadi } \\
\text { Chartopolis }\end{array}$ & $\begin{array}{l}32^{\circ} 50.779 \\
22^{\circ} 09.619\end{array}$ & ML12-6 & 508 & $\begin{array}{c}\text { Dense } \\
\text { Mediterranean } \\
\text { woodland: } A S, P, \\
\text { JO, } Z S, P L,\end{array}$ & 75 & 45 & $\begin{array}{l}\text { Pistacia } \\
\text { lentiscus }\end{array}$ & 3 & 1 & 7 & $\begin{array}{l}\text { May } \\
2012\end{array}$ \\
\hline \multirow[t]{3}{*}{$\begin{array}{l}\text { Gebel } \\
\text { Akhdar }\end{array}$} & $\begin{array}{l}32^{\circ} 40.038 \\
21^{\circ} 51.789\end{array}$ & ML12-9 & 798 & $\begin{array}{c}\text { Grassy steppe } \\
\text { scrub: } S S, P H, Z S\end{array}$ & 70 & 40 & Zizyphus & 3 & 1 & 6 & $\begin{array}{l}\text { May } \\
2012\end{array}$ \\
\hline & $\begin{array}{l}32^{\circ} 39.647 \\
21^{\circ} 51.308\end{array}$ & $\begin{array}{c}\text { ML12- } \\
10 \\
\end{array}$ & 853 & $\begin{array}{c}\text { Steppe Scrub: SS, } \\
\text { PH, ZS }\end{array}$ & 70 & 35 & Zizyphus & 3 & 2 & 5 & $\begin{array}{l}\text { May } \\
2012 \\
\end{array}$ \\
\hline & $\begin{array}{l}32^{\circ} 31.574 \\
21^{\circ} 47.025\end{array}$ & $\begin{array}{l}\text { ML12- } \\
11\end{array}$ & 710 & $\begin{array}{c}\text { Steppe Scrub: } \\
A S, P H, Z S\end{array}$ & 50 & 5 & Poacae & 0 & 0 & 3 & $\begin{array}{l}\text { May } \\
2012 \\
\end{array}$ \\
\hline
\end{tabular}

Table 2: Details of sample sites for modern sampling for mollusc and vegetation. $\mathrm{PL}=$ Pistacia lentiscus; $\mathrm{PH}=$ Phlomis sp.; JO = Juniperus oxycedrus; $\mathrm{RT}=$ Rhus tripartia; $\mathrm{CS}=$ Ceratonia silaqua; $\mathrm{SS}=$ Sarcopoterium spinosum; $\mathrm{AS}=$ Artemisia sp.; $\mathrm{P}=$ Poacae; $\mathrm{Z}=$ Zizyphus sp.

A total of $37 \mathrm{H}$. melanostoma were selected for ${ }^{14} \mathrm{C}$ analysis with a minimum of three specimens analysed from each sample location. Vegetation and soil samples were gathered from every sample site where live molluscs were collected. Where possible samples of vegetation were gathered in association with live molluscs. In selecting samples for atmospheric and dietary ${ }^{14} \mathrm{C}$ values species favored by $\mathrm{H}$. melanostoma were selected in accordance with existing ecological knowledge of the species (e.g. Brandt 1959) and 
observations made in the field. Where such species (Table 2) were unavailable, dominant vegetation was sampled. Once collected, molluscs were killed by freezing. Freeze dried bodies were separated from the shell using forceps.

\section{Radiocarbon}

Whole shells were carefully broken apart using forceps or a Dremel tool with a circular carborundum cutting head. An aperture sample was obtained from every adult $H$. melanostoma that was dated (Figure 3). In small specimens with less than one full season of growth the entire shell was sampled and considered as an apex because the aperture had not thickened and so was too insubstantial for effective analysis.

Many previous radiocarbon studies, which were concerned primarily with predicting the 'limestone effect', did not assess lifetime changes in apparent ${ }^{14} \mathrm{C}$ age (e.g. Quarta et al., 2007; Romanellio et al., 2008; Pigati et al., 2010; Xu et al., 2011). Investigations of parts of the shell were carried out to evaluate changes in apparent radiocarbon age over the lifetime of the individual snail (Figure 3). At least two paired aperture/apex dates were obtained from adult specimens for every location sampled except for the environment immediately outside the Haua Fteah where all the apices were used in a related $\delta^{13} \mathrm{C}$ shell study (Prendergast 2013; Prendergast et al., 2015), looking at the suitability of $\mathrm{H}$. melanostoma for climatic reconstruction. In some instances whorl segments were also selected to provide further detail.

Figure 3. Diagram of $H$. melanostoma showing parts selected for sampling. The stippling shows the dark brown areas on the shell after which the species is named.

Vegetation samples for ${ }^{14} \mathrm{C}$ analysis were rinsed in distilled water and dried weighed into a pre-combusted quartz tube with an excess of copper oxide ( $\mathrm{CuO}$ ), sealed under vacuum and combusted to carbon dioxide $\left(\mathrm{CO}_{2}\right)$ and converted to graphite using the hydrogen reduction method (Vogel et al., 1987). Shell samples were pre-treated using $1 \% \mathrm{HCl}$ to remove any surface contamination and then rinsed in distilled water, dried and weighed. The samples were then placed in to septa seal containers and converted into $\mathrm{CO}_{2}$ using $80 \%$ phosphoric acid. The resulting $\mathrm{CO}_{2}$ converted to graphite on an iron catalyst using the zinc reduction method (Slota et al., 1987). The ${ }^{14} \mathrm{C} /{ }^{12} \mathrm{C}$ and ${ }^{13} \mathrm{C} /{ }^{12} \mathrm{C}$ ratios were measured by accelerator mass spectrometry (AMS) at the 14 CHRONO Centre, Queen's University Belfast. The ${ }^{14} \mathrm{C} /{ }^{12} \mathrm{C}$ ratio of the vegetation and shell samples were background corrected using measurements of anthracite and Icelandic Spar Calcite, respectively, and normalised to the HOXII standard (SRM 4990C; National Institute of Standards and Technology). The radiocarbon ages were corrected for isotope fractionation using the AMS measured ${ }^{13} \mathrm{C} /{ }^{12} \mathrm{C}$, which accounts for both natural and machine fractionation. The radiocarbon age and one standard deviation were calculated using the Libby half-life of 5568 years following the methods of Stuiver and Polach (1977). ${ }^{14} \mathrm{C}$ data for modern samples are presented as $\mathrm{F}^{14} \mathrm{C}$ values (Reimer et al., 2004). The $1 \sigma$ uncertainties are the maximum of the measurement statistics and the variance of seven two-minute runs for each sample. Throughout this paper, ${ }^{14} \mathrm{C}$ ages reported in tables are not rounded as this may introduce errors in calculations (Millard 2014).

\section{Stable Isotopes}


Stable carbon analysis of vegetation and soil was carried out at the ${ }^{14} \mathrm{CHRONO}$ Centre at Queen's University Belfast. Stable isotopes $\left(\delta^{13} \mathrm{C}\right.$ and $\left.\delta^{15} \mathrm{~N}\right), \%$ carbon and \% nitrogen from vegetation and soil samples were measured on a Thermo Fisher Delta $V$ Advantage with elemental analyser together with Iso-Analytical Laboratory Standard IA-R041 L-Alanine $\left(\delta^{15} \mathrm{~N}_{\mathrm{AIR}}=5.56 \% ; \delta^{13} \mathrm{C}_{\mathrm{VPDB}}=23.33 \%\right.$ o) which was measured 11 to 13 times throughout the runs, bracketing between 6 and 8 samples.

\section{Modelling and Data Analysis}

Data analysis was carried out using Microsoft Excel 2013 and SPSS version 19. Simple and exponential linear regression and Chi Square $\left(\chi_{i}{ }^{2}\right)$ were used to investigate relationships between variables. Weighted averages of multiple samples and Chi square tests were calculated using a VBA coded macro in Excel based on Bevington (1969). The basic relationships between radiocarbon results from different sites were evaluated using chisquared $\left(\chi_{i}^{2,0.5}\right)$ analysis and analysis of correlations and sample scatter (standard deviation).

$\mathrm{F}^{14} \mathrm{C}$ values for shells, where apertures, apices and whorl fragments were measured, and where required, combined for certain analyses of the radiocarbon ecology of $H$. melanostoma. This was done by calculating the weighted averages of the $\mathrm{F}^{14} \mathrm{C}$ values to simulate analysis of the whole shell (Table 6). Because the aperture and apex $\mathrm{F}^{14} \mathrm{C}$ values should represent maximum range of $\mathrm{F}^{14} \mathrm{C}$ values in a land snail across its growth cycles, the resultant average $\mathrm{F}^{14} \mathrm{C}$ and its aggregated error should represent a reasonable average $\mathrm{F} 14 \mathrm{C}$ value for a sample across its whole life span. This was further tested by the measurement of a number of whorl fragments to determine intermediate values.

Predicted $\delta^{13} \mathrm{C}$ values were calculated using the method set out in Stott (2002). The Stott equation is based on a linear regression between snail body $\delta^{13} \mathrm{C}$ and snail shell $\delta^{13} \mathrm{C}$. The values used in this study were first calculated in Prendergast (2013) and snail body $\delta^{13} \mathrm{C}$ and shell $\delta^{13} \mathrm{C}$ for samples comes from Prendergast et al., (2014). While the equation was originally created for $\mathrm{H}$. aspersa rather than $\mathrm{H}$. melanostoma, the two species occupy similar niches in different areas around the Mediterranean and ecological observations suggest that $H$. melanostoma is locally being out-competed by introduced $H$. aspersa, particularly in urban areas. It is important to note that there may be further species-specific offsets that may impact detailed comparison with such values.

Calculation of the difference between $\mathrm{F}^{14} \mathrm{C}$ of mollusc shells and $\mathrm{F}^{14} \mathrm{C}$ of preferred vegetation diet for $H$. melanostoma, equation (1), was used to model the potential impact of old carbon on individual shells (e.g. Pigati et al., 2010).

$$
\mathrm{F}^{14} \mathrm{C}_{\text {Shell Average }}-\mathrm{F}^{14} \mathrm{C}_{\text {diet }}=\mathrm{F}^{14} \mathrm{C} \text { from non-dietary sources }
$$

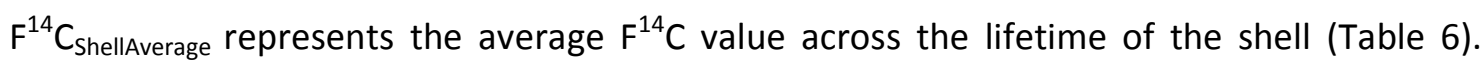
$\mathrm{F}^{14} \mathrm{C}_{\text {diet }}$ is derived using $\mathrm{F}^{14} \mathrm{C}$ atmospheric values for vegetation consumed by $H$. melanostoma gathered from sample sites (Table 5). In instances where more than one value exists for $\mathrm{F}^{14} \mathrm{C}_{\text {atmosphere }}$ from a site, a weighted average was used for the value of $\mathrm{F}^{14} \mathrm{C}_{\text {diet. }}$.

This method follows the understanding that the total quantity of $\mathrm{F}^{14} \mathrm{C}$ present in a mollusc shell can only derive from three overall sources, dietary carbon, respiration and hydration. Of these, only dietary carbon is likely to be significant in the vast majority of cases where snails pass most of their lives on or above the soil surface. Dietary carbon will have two 
components; 'young', derived from living tissue, and 'old', derived from dead tissue or mineral sources. If the $\mathrm{F}^{14} \mathrm{C}$ of the vegetation eaten by the snail can be established, then the remaining difference between the $\mathrm{F}^{14} \mathrm{C}$ of the shell and the $\mathrm{F}^{14} \mathrm{C}$ of the diet should represent the quantity that the shell's $\mathrm{F}^{14} \mathrm{C}$ value has been reduced through the incorporation of older carbon, even if the exact source of carbon contributing to the difference cannot be fully known.

The age offset in ${ }^{14} \mathrm{C}$ years, the 'old carbon effect' as discussed in this study, where used, was calculated using the following equation (2):

$$
\text { Shell Reservoir Offset }=-8033 * \ln \left(\frac{F 14 \text { Cshell }}{F 14 \text { Catm }}\right)
$$

This equation was defined after Keaveney \& Reimer (2012), $\mathrm{F}^{14} \mathrm{C}_{\text {shell }}=\mathrm{F}^{14} \mathrm{C}$ value derived from the land snail shell. The -8033 is derived from the Libby half-life of ${ }^{14} \mathrm{C}\left(\mathrm{T}_{1 / 2}=5568\right.$ years). Atmosphere values; $\mathrm{F}^{14} \mathrm{C}_{\mathrm{atm}}$, in this study are based primarily on vegetation samples gathered at sample sites for live land snails in the year of collection (2010 and 2012) as the Northern Hemisphere Zone 2 dataset (Hua et al., 2013) is only current until late 2009 and Levin et al., (2013) does not have any data points with sufficient geographic proximity.

The uncertainty that is associated with each reservoir offset is calculated using the uncertainty associated with the radiocarbon measurement $\left(\mathrm{F}^{14} \mathrm{C}_{\text {shell }}\right)$ from each modern shell sample and its associated uncertainty $\mathrm{F}^{14}$ Csigma using the equation (3) below (Soulet et al., 2016).

$$
\text { sigma }=8033 * \sqrt{\left(\frac{F^{14} C \text { Shell Sigma }}{F^{14} C \text { Shell measured }}\right)^{2}+\left(\frac{F^{14} C \text { atm sigma }}{F^{14} C \text { atm measured }}\right)^{2}}
$$

\section{Results}

$59{ }^{14} \mathrm{C}$ analyses were made from 32 live $H$. melanostoma over the course of the field sampling exercises. The results of the $\delta^{13} \mathrm{C}$ on vegetation (Table 3 ), ${ }^{14} \mathrm{C}$ of vegetation (Table 4), ${ }^{14} \mathrm{C}$ of shells (Table 5) and modelling of ${ }^{14} \mathrm{C}$ shell data and old carbon impact (Table 6) are presented here.

\begin{tabular}{|l|l|l|l|}
\hline Sample Site ID & \multicolumn{1}{|c|}{ Genus } & \multicolumn{1}{|c|}{ Sample Type } & \multicolumn{1}{|c|}{$\mathbf{\delta}^{\mathbf{3}} \mathbf{C}_{\text {VPDB }} \%$} \\
\hline $1546^{* 1}$ & Quercus sp. & Bulk Vegetation & -27.6 \\
\hline $1546^{* 1}$ & Quercus sp. & Bulk Vegetation & -27.6 \\
\hline HF12 Eco02 & Juniperus oxycedrus & Bulk Vegetation & -22.6 \\
\hline HF12 Eco02 & Juniperus oxycedrus & Bulk Vegetation & -22.7 \\
\hline HF12 Eco05 & Juniperus oxycedrus & Bulk Vegetation & -24.4 \\
\hline HF12 Eco05 & Juniperus oxycedrus & Bulk Vegetation & -24.4 \\
\hline HF12 Eco06 & Juniperus oxycedrus & Bulk Vegetation & -23.9 \\
\hline HF12 Eco06 & Juniperus oxycedrus & Bulk Vegetation & -23.9 \\
\hline HF12 Eco06 & Ceratonia siliqua & Bulk Vegetation & -30.0 \\
\hline HF12 Eco06 & Ceratonia siliqua & Bulk Vegetation & -30.0 \\
\hline AP12-1 & Artemisia spp. & Bulk Vegetation & -28.9 \\
\hline MH12-6 & Pistacia lentiscus & Bulk Vegetation & -27.1 \\
\hline MH12-6 & Sarcopoterium spinosum & Bulk Vegetation & -28.7 \\
\hline
\end{tabular}




\begin{tabular}{|l|l|l|l|}
\hline MH12-6 & Ziziphus sp. & Bulk Vegetation & -26.0 \\
\hline MH12-9 & Ziziphus sp. & Bulk Vegetation & -25.4 \\
\hline MH12-10 & Ziziphus sp. & Bulk Vegetation & -25.4 \\
\hline MH12-11 & Triticeae & Bulk Vegetation & -27.5 \\
\hline HF12 Eco02 & n/a & Soil & -25.0 \\
\hline HF12 Eco02 & n/a & Soil & -25.0 \\
\hline HF12 Eco06 & n/a & Soil & -24.9 \\
\hline HF12 Eco06 & n/a & Soil & -24.9 \\
\hline
\end{tabular}

Table 3. $\delta^{13} \mathrm{C}$ of vegetation and soil samples from across Cyrenaica. * 1 - Sample 1546 was gathered from outside the Haua Fteah.

\begin{tabular}{|l|l|l|l|l|l|}
\hline $\begin{array}{l}\text { Sample } \\
\text { location }\end{array}$ & Genus & $\begin{array}{l}\text { Alt. } \\
(\mathbf{m})\end{array}$ & UBA & $\begin{array}{l}\mathbf{F}^{14} \mathbf{C} \\
\text { vegetation }\end{array}$ & $\mathbf{\pm}$ \\
\hline $\begin{array}{l}\text { Haua } \\
\text { Fteah }\end{array}$ & Ceratonia & 70 & 18083 & 1.0571 & 0.003 \\
\hline $\begin{array}{l}\text { Haua } \\
\text { Fteah }\end{array}$ & leaf litter & 70 & 18085 & 1.1079 & 0.0029 \\
\hline $\begin{array}{l}\text { Apollonia } \\
\text { Wadi } \\
\text { Chartopolis }\end{array}$ & Ceratonia & 508 & 25905 & 1.0337 & 0.0034 \\
\hline $\begin{array}{l}\text { Wadi } \\
\text { Chartopolis }\end{array}$ & Pistacia & 508 & 25906 & 1.0373 & 0.0029 \\
\hline $\begin{array}{l}\text { Gebel } \\
\text { Akhdar 1 }\end{array}$ & Zizyphus & 798 & 25907 & 1.0381 & 0.0029 \\
\hline $\begin{array}{l}\text { Gebel } \\
\text { Akhdar 2 }\end{array}$ & Zizyphus & 853 & 25908 & 1.0314 & 0.0029 \\
\hline $\begin{array}{l}\text { Gebel } \\
\text { Akhdar 3 }\end{array}$ & Poacae & 710 & 25909 & 1.0463 & 0.0043 \\
\hline
\end{tabular}

Table 4. Radiocarbon results of vegetation samples taken from across Cyrenaica as a proxy for atmospheric ${ }^{14} \mathrm{C}$ and dietary $\mathrm{F}^{14} \mathrm{C}$ for land snails. Average dietary $\mathrm{F}^{14} \mathrm{C}$ of suggested mollusc diet is based on the per site values presented in this table.

\begin{tabular}{|c|c|c|c|c|c|c|c|c|c|c|c|}
\hline $\begin{array}{c}\text { UBA } \\
\text { Aperture }\end{array}$ & $\begin{array}{c}\text { UBA } \\
\text { Whorl } \\
\text { Frag. }\end{array}$ & $\begin{array}{c}\text { UBA } \\
\text { Apices }\end{array}$ & Sample Site ID & $\begin{array}{c}\mathbf{F}^{14} \mathbf{C} \\
\text { Apertures }\end{array}$ & $\mathbf{\pm}$ & $\begin{array}{c}\mathbf{F}^{14} \mathbf{C} \\
\text { Whorl } \\
\text { Frag. }\end{array}$ & $\mathbf{E}$ & $\begin{array}{c}\mathbf{F}^{14} \mathbf{C} \\
\text { Apices }\end{array}$ & \pm & $\begin{array}{c}\mathbf{F}^{14} \mathbf{C} \\
\text { Average }\end{array}$ & \pm \\
\hline 16927 & 17562 & & HF_Eco02 & 0.9820 & 0.0028 & 1.0070 & 0.0031 & & & 0.9945 & 0.0030 \\
\hline 16928 & 17563 & & HF_Eco02 & 1.0003 & 0.0026 & 1.0190 & 0.0032 & & & 1.0097 & 0.0029 \\
\hline 16929 & 17564 & & HF_Eco02 & 1.0180 & 0.0028 & 1.0340 & 0.0030 & & & 1.0260 & 0.0029 \\
\hline 16930 & 17565 & & HF_Eco02 & 0.9626 & 0.0026 & 0.9650 & 0.0030 & & & 0.9638 & 0.0028 \\
\hline 17566 & & & HF_Eco02 & 1.0233 & 0.0033 & & & & & 1.0233 & 0.0033 \\
\hline 17567 & & & HF_Eco03 & 0.9640 & 0.003 & & & & & 0.9640 & 0.0030 \\
\hline 17568 & & & HF_Eco03 & 1.0040 & 0.0033 & & & & & 1.0040 & 0.0033 \\
\hline 17569 & & & HF_Eco03 & 1.0227 & 0.0030 & & & & & 1.0227 & 0.0030 \\
\hline 17570 & & & HF_Eco04 & 1.0633 & 0.0032 & & & & & 1.0633 & 0.0032 \\
\hline 17571 & & & HF_Eco05 & 0.9818 & 0.0032 & & & & & 0.9818 & 0.0032 \\
\hline 17572 & & & HF_Eco05 & 0.9759 & 0.0028 & & & & & 0.9759 & 0.0028 \\
\hline 16931 & 17573 & & HF_Eco06 & 0.9920 & 0.0026 & 1.0070 & 0.0029 & & & 0.9995 & 0.0028 \\
\hline 16932 & 17574 & & HF_Eco06 & 1.0167 & 0.0026 & 1.0070 & 0.0034 & & & 1.0119 & 0.0030 \\
\hline 17575 & & & HF_Eco06 & 1.0380 & 0.0031 & & & & & 1.0380 & 0.0031 \\
\hline
\end{tabular}




\begin{tabular}{|c|c|c|c|c|c|c|c|c|c|c|c|}
\hline 17577 & & & HF_Eco06 & 1.0227 & 0.0032 & & & & & 1.0227 & 0.0032 \\
\hline 17578 & & & HF_Eco06 & 1.0093 & 0.0033 & & & & & 1.0093 & 0.0033 \\
\hline 17579 & & & HF_Eco06 & 1.0055 & 0.0030 & & & & & 1.0055 & 0.0030 \\
\hline 17580 & & & HF_Eco06 & 1.0021 & 0.0030 & & & & & 1.0021 & 0.0030 \\
\hline 18082 & & & HF_Eco06 & 1.0428 & 0.0040 & & & & & 1.0428 & 0.0040 \\
\hline 21757 & & 21756 & HF12 Apollonia & 0.8891 & 0.0025 & & & 0.8511 & 0.0028 & 0.8701 & 0.0027 \\
\hline \multirow[t]{4}{*}{21760} & & 21759 & HF12 Apollonia & 0.8743 & 0.0026 & & & 0.8561 & 0.0037 & 0.8652 & 0.0032 \\
\hline & & 21758 & HF12 Apollonia & & & & & 0.8186 & 0.0032 & 0.8186 & 0.0032 \\
\hline & & 21761 & HF12 Apollonia & & & & & 0.8469 & 0.0036 & 0.8469 & 0.0036 \\
\hline & & 21762 & HF12 Apollonia & & & & & 0.8773 & 0.0039 & 0.8773 & 0.0039 \\
\hline 21749 & & 21748 & HF12 Resthouse & 0.9536 & 0.0026 & & & 0.8970 & 0.0030 & 0.9253 & 0.0028 \\
\hline 21751 & & 21750 & HF12 Resthouse & 0.9820 & 0.0026 & & & 0.8530 & 0.0025 & 0.9175 & 0.0026 \\
\hline 21753 & & 21752 & HF12 Resthouse & 0.8801 & 0.0024 & & & 0.8396 & 0.0026 & 0.8599 & 0.0025 \\
\hline \multirow[t]{2}{*}{21755} & & 21754 & HF12 Resthouse & 0.9863 & 0.0034 & & & 0.9262 & 0.0038 & 0.9563 & 0.0036 \\
\hline & & 21773 & ML12-6 - Chart. & & & & & 0.9575 & 0.0038 & 0.9575 & 0.0038 \\
\hline 21775 & & 21774 & ML12-6 - Chart. & 0.9934 & 0.0049 & & & 0.9834 & 0.0041 & 0.9884 & 0.0045 \\
\hline 21778 & 21777 & 21776 & ML12-6 - Chart. & 0.9659 & 0.0027 & 0.9015 & 0.0027 & 0.9155 & 0.0027 & 0.9276 & 0.0027 \\
\hline 21780 & & 21779 & ML12-9-Geb1 & 0.9876 & 0.0028 & & & 0.9220 & 0.0033 & 0.9548 & 0.0031 \\
\hline \multirow[t]{2}{*}{21782} & & 21781 & ML12-9-Geb1 & 1.0064 & 0.0028 & & & 0.9975 & 0.0028 & 1.0020 & 0.0028 \\
\hline & & 21783 & ML12-9-Geb1 & 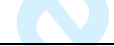 & & & & 0.9116 & 0.0037 & 0.9116 & 0.0037 \\
\hline 21785 & & 21784 & ML12-10-Geb2 & 0.9651 & 0.0027 & & & 0.9456 & 0.0027 & 0.9554 & 0.0027 \\
\hline 21787 & & 21786 & ML12-10-Geb2 & 1.0066 & 0.0028 & & & 0.9353 & 0.0026 & 0.971 & 0.0027 \\
\hline 21789 & & 21788 & ML12-10-Geb2 & 0.9270 & 0.0028 & & & 0.8932 & 0.0029 & 0.9101 & 0.0029 \\
\hline
\end{tabular}

Table 5. Radiocarbon and stable isotope results and analysis on apertures, whorl fragments, apices and aggregated ages of $\mathrm{H}$. melanostoma from the Cyrenaica region of Libya.

\begin{tabular}{|c|c|c|c|c|c|c|c|c|c|c|c|c|c|c|c|c|}
\hline $\begin{array}{c}\text { UBA } \\
\text { Aperture }\end{array}$ & \begin{tabular}{|c|} 
UBA \\
Whorl \\
Frag.
\end{tabular} & $\begin{array}{c}\text { UBA } \\
\text { Apices }\end{array}$ & $\begin{array}{l}\text { Sample } \\
\text { Site ID }\end{array}$ & $\begin{array}{c}\mathbf{F}^{14} \mathbf{C} \\
\text { Averag } \\
\mathrm{e}^{*_{1}}\end{array}$ & g & $\mathrm{F}^{14} \mathrm{C}$ diet & \pm & $\begin{array}{c}\mathbf{F}^{14} \mathbf{C} \\
\text { Average } \\
\text { minus } \\
\mathbf{F}^{14} \mathbf{C} \text { diet }\end{array}$ & t & $\begin{array}{c}\mathbf{F}^{14} \mathbf{C} \\
\text { diff. as } \\
\%\end{array}$ & $\begin{array}{c}\text { Age } \\
\text { offset } \\
\left({ }^{14} \text { C yrs }\right)\end{array}$ & \pm & $\begin{array}{c}\text { Measur } \\
\text { ed } \delta^{13} \mathrm{C} \\
\text { Shell } \\
\text { VPDB }\end{array}$ & 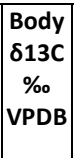 & \begin{tabular}{|c|} 
Predicte \\
$\mathrm{d} \delta^{13} \mathrm{c}$ \\
Shell
\end{tabular} & $\begin{array}{c}\text { Predicted } \\
\delta^{13} \mathrm{C} \text { minus } \\
\text { Measured } \\
\delta^{13} \mathrm{C}\end{array}$ \\
\hline 16927 & 17562 & & HF_Eco02 & 0.9945 & 0.003 & 1.0571 & 0.0030 & -0.0626 & 0.0042 & $-6.26 \%$ & 490 & 33 & -10.3 & -23.4 & -9.9 & 0.4 \\
\hline 16928 & 17563 & & HF_Eco02 & 1.0097 & 0.0029 & 1.0571 & 0.0030 & -0.0475 & 0.0042 & $-4.75 \%$ & 369 & 32 & -10.4 & -24.1 & -10.6 & -0.2 \\
\hline 16929 & 17564 & & HF_Eco02 & 1.026 & 0.0029 & 1.0571 & 0.0030 & -0.0311 & 0.0042 & $-3.11 \%$ & 240 & 32 & -10.3 & 24.4 & -10.8 & -0.5 \\
\hline 16930 & 17565 & & HF_Eco02 & 0.9638 & 0.0028 & 1.0571 & 0.0030 & -0.0933 & 0.0041 & $-9.33 \%$ & 742 & 33 & -10.8 & 23.9 & -10.4 & 0.4 \\
\hline 17566 & & & HF_Eco02 & 1.0233 & 0.0033 & 1.0571 & 0.0030 & -0.0338 & 0.0045 & $-3.38 \%$ & 261 & 35 & -10.2 & -23.6 & -10.1 & 0.1 \\
\hline 17567 & & & HF_Eco03 & 0.964 & 0.003 & 1.0571 & 0.0030 & -0.0931 & 0.0042 & $-9.31 \%$ & 741 & 34 & -10.5 & -23.8 & -10.3 & 0.2 \\
\hline 17568 & & & HF_Eco03 & 1.004 & 0.0033 & 1.0571 & 0.0030 & -0.0531 & 0.0045 & $-5.31 \%$ & 414 & 35 & -10 & -23.7 & -10.2 & -0.2 \\
\hline 16932 & 17574 & & HF_Eco06 & 1.0119 & 0.003 & 1.0571 & 0.0030 & -0.0453 & 0.0042 & $-3.44 \%$ & 351 & 33 & -11.6 & -25.2 & -11.6 & 0 \\
\hline 17575 & & & HF_Eco06 & 1.038 & 0.0031 & 1.0571 & 0.0030 & -0.0191 & 0.0043 & $0.62 \%$ & 146 & 33 & -11.8 & -25.7 & -12 & -0.2 \\
\hline 17577 & & & HF_Eco06 & 1.0227 & 0.0032 & 1.0571 & 0.0030 & -0.0344 & 0.0044 & $-7.53 \%$ & 266 & 34 & -11.2 & -23.3 & -9.8 & 1.4 \\
\hline 17578 & & & HF_Eco06 & 1.0093 & 0.0033 & 1.0571 & 0.0030 & -0.0478 & 0.0045 & $-8.12 \%$ & 372 & 35 & -11.5 & -23.9 & -10.4 & 1.1 \\
\hline 17579 & & & HF_Eco06 & 1.0055 & 0.003 & 1.0571 & 0.0030 & -0.0516 & 0.0042 & $-5.76 \%$ & 402 & 33 & -11.9 & -24.9 & -11.3 & 0.6 \\
\hline 17580 & & & HF_Eco06 & 1.0021 & 0.003 & 1.0571 & 0.0030 & -0.0550 & 0.0042 & $-4.53 \%$ & 429 & 33 & -11 & -24.8 & -11.2 & -0.2 \\
\hline 18082 & & & HF_Eco06 & 1.0428 & 0.004 & 1.0571 & 0.0030 & -0.0143 & 0.0050 & $-1.91 \%$ & 109 & 38 & -10.7 & -24.4 & -10.9 & -0.2 \\
\hline 21757 & & 21756 & $\begin{array}{l}\text { HF12 } \\
\text { Apollonia }\end{array}$ & 0.8701 & 0.0027 & 1.0501 & 0.0031 & -0.18 & 0.0041 & $-3.44 \%$ & 1510 & 34 & -11.2 & -27.3 & -13.9 & -2.7 \\
\hline 21751 & & 21750 & HF12 & 0.9175 & 0.0026 & 1.0388 & 0.0030 & -0.1213 & 0.0039 & $-4.78 \%$ & 997 & 33 & -9.9 & -29.5 & -11.4 & -1.5 \\
\hline
\end{tabular}




\begin{tabular}{|c|c|c|c|c|c|c|c|c|c|c|c|c|c|c|c|c|}
\hline & & & Resthouse & & & & & & & & & & & & & \\
\hline 21753 & & 21752 & \begin{tabular}{|l|} 
HF12 \\
Resthouse
\end{tabular} & 0.8599 & 0.0025 & 1.0388 & 0.0030 & -0.179 & 0.0039 & $-5.16 \%$ & 1518 & 33 & -10.8 & -25.4 & -13.8 & -3 \\
\hline \multirow[t]{2}{*}{21755} & & 21754 & \begin{tabular}{|l|} 
HF12 \\
Resthouse
\end{tabular} & 0.9563 & 0.0036 & 1.0388 & 0.0030 & -0.0826 & 0.0047 & $-5.50 \%$ & 665 & 38 & -10.8 & -24.6 & -12.4 & -1.6 \\
\hline & & 21773 & $\begin{array}{l}\text { ML12-6 } \\
\text { Chart. }\end{array}$ & 0.9575 & 0.0038 & 1.0358 & 0.0018 & -0.0783 & 0.0042 & $-1.43 \%$ & 631 & 35 & -12.3 & -24.9 & -15.7 & -3.4 \\
\hline 21775 & & 21774 & $\begin{array}{l}\text { ML12-6 } \\
\text { Chart. }\end{array}$ & 0.9884 & 0.0045 & 1.0358 & 0.0018 & -0.0474 & 0.0032 & $-18.00 \%$ & 376 & 39 & -12 & -27.5 & -14.6 & -2.6 \\
\hline 21778 & 21777 & 21776 & $\begin{array}{l}\text { ML12-6 } \\
\text { Chart. }\end{array}$ & 0.9276 & 0.0027 & 1.0358 & 0.0018 & -0.1082 & 0.0042 & $-18.49 \%$ & 886 & 27 & -9.6 & -26.0 & -11.8 & -2.2 \\
\hline 21780 & & 21779 & $\begin{array}{l}\text { ML12-9- } \\
\text { Geb1 }\end{array}$ & 0.9548 & 0.0031 & 1.0381 & 0.0029 & -0.0833 & 0.0040 & $-23.15 \%$ & 672 & 34 & -10.3 & -24.2 & -10.7 & -0.4 \\
\hline 21782 & & 21781 & $\begin{array}{l}\text { ML12-9- } \\
\text { Geb1 }\end{array}$ & 1.002 & 0.0028 & 1.0381 & 0.0029 & -0.0362 & 0.0047 & $-20.32 \%$ & 284 & 32 & -9.7 & -25.4 & -11.8 & -2.1 \\
\hline 21785 & & 21784 & $\begin{array}{l}\text { ML12-10- } \\
\text { Geb2 }\end{array}$ & 0.9554 & 0.0027 & 1.0314 & 0.0029 & -0.0761 & 0.0040 & $-17.28 \%$ & 615 & 32 & -10.5 & -25.7 & -12.1 & -1.6 \\
\hline 21787 & & 21786 & \begin{tabular}{|l|} 
ML12-10- \\
Geb2
\end{tabular} & 0.971 & 0.0027 & 1.0314 & 0.0029 & -0.0605 & 0.0040 & $-11.35 \%$ & 485 & 32 & -10.9 & -25.9 & -12.3 & -1.4 \\
\hline 21789 & & 21788 & \begin{tabular}{|l|} 
ML12-10- \\
Geb2
\end{tabular} & 0.9101 & 0.0029 & 1.0314 & 0.0029 & -0.1213 & 0.0041 & $-12.13 \%$ & 1005 & 34 & -11.1 & -25.7 & -13.4 & -2.3 \\
\hline
\end{tabular}

Table 6. Table showing the limestone effect observed in sampled molluscs in the form of differences in $\mathrm{F}^{14} \mathrm{C}$ values between dietary sources and shells across the Gebel Akhdar.*1 $\mathrm{F}^{14} \mathrm{C}$ Shell Average is calculated based on the median $\mathrm{F}^{14} \mathrm{C}$ value for samples taken from specific shells. Estimation of old carbon content was based on the methods set out in Pigati et al., (2010). Data paired with $\delta^{13} C_{\text {Shell }}$ and $\delta^{13} C_{\text {Body }}$ values measured by IRMS (not machine measurement from the AMS) on selected samples (Prendergast 2013) and $\delta^{13} \mathrm{C}$ predicted was calculated using the method described in Stott (2002).

\section{Biometrics}

Biometrics were gathered for all $\mathrm{H}$. melanostoma specimens sampled for ${ }^{14} \mathrm{C}$ dating. Mean Basal Diameter (MBD) Height and growth checks were measured for all samples. The mean MBD for all specimens was $21.3 \mathrm{~mm}$, Mean height was $18 \mathrm{~mm}$ and the average number of growth checks was 2.4 . The largest MBD was $28.7 \mathrm{~mm}$ while the smallest was $7.3 \mathrm{~mm}$. Those with the smallest MBD and Height were all found in Apollonia (AP12).

\section{Within-shell radiocarbon variation}

There was a substantial but predictable 'age' difference between apices and apertures, (Figure 4), with apices being 'older' than apertures. This is significant for ${ }^{14} \mathrm{C}$ dating as it suggests that juvenile specimens may have a higher propensity towards old carbon intake than adult specimens. It is also important for archaeologists selecting dating samples because apices and aperture fragments are easily identifiable and preserve well. Whorl fragments, where analysed, were found to more closely reflect values of apertures (Table 5) rather than more broadly intermediate ages. In ecological terms it is likely that young snails require calcium (Ca) to start building a shell, obtaining it from small limestone particles in the soil, from outcrops, or even dead snail shell. They may also start life grazing algal biofilms on the soil/rocks. Generally growth banding suggests lifespans of 2-5 growth seasons. In adults the shell may grow less rapidly and the snail seems to get a proportionally larger quantity of their calcium through grazing vegetation. More homogenous and higher $\mathrm{F}^{14} \mathrm{C}$ values in aperture and whorl samples could reflect the high ecological mobility of adult specimens (Kerney et al., 1983) and would also explain why no $\mathrm{H}$. melanostoma were collected in proximity to Juniperus, since gymnosperms such as this notoriously acidify soils (Augusto et al., 2015) and such environments are not preferred by land snails. This may also account for older average 
'ages' and wider variation in $H$. melanostoma specimens gathered in some parts of the Gebel Akhdar transect where the primary vegetation is Juniperus rather than Ceratonia or Pistacia which would not acidify the soil in the same way. In these regions there is also significantly less vegetation cover and poorer overall diversity potentially driving land snails such as $\mathrm{H}$. melanostoma to seek carbonates from non-vegetative sources and exacerbating the 'old carbon effect' where it occurs.

Figure 4. Boxplot of $\mathrm{F}^{14} \mathrm{C}$ of $\mathrm{H}$. melanostoma apices and apertures by site: ML12_6,9,10: wt. average of aperture and apices values $(n=9)$ from sample sites on the Gebel Akhdar. AP_12: Apollonia (Susa) ( $n=2 ; R H \_12$ : Project Resthouse (Shahat)( $\left.n=4\right)$. Individual data points are displayed within the box plot as ' + '.

\section{Regional Trends in the Radiocarbon Ecology of Helix melanostoma}

Regional trends in the data are present. Comparison of the differences between $\mathrm{F}^{14} \mathrm{C}_{\text {apertures }}$ and $\mathrm{F}^{14} \mathrm{C}_{\text {apices }}$ values with levels of total vegetation finds weak but significant correlations for both apertures and apices (Table S1). This relation was found to improve noticeably if $\mathrm{F}^{14} \mathrm{C}$ values were compared specifically with arboreal cover (Table 4). There is an even more pronounced association between vegetation cover and variations in $\mathrm{F}^{14} \mathrm{C}_{\text {wholeshell }}$ values (Figure 5 [a]) that also show a weak but significant correlation and demonstrates a clear positive trend between increased total vegetation cover and higher $\mathrm{F}^{14} \mathrm{C}$ values. This correlation is further improved when arboreal cover is compared directly to $\mathrm{F}^{14} \mathrm{C}_{\text {wholeshell }}$ values (Figure $5[\mathrm{~b}]$ ). The observed relationship between $\mathrm{F}^{14} \mathrm{C}$ values with vegetation cover suggests that the underlying ecological behaviour of juvenile and adult $\mathrm{H}$. melanostoma is quite similar in terms of the vegetation they consume across all the sample sites. It is interesting that this correlation is noticeably stronger in the combined $\mathrm{F}^{14} \mathrm{C}_{\text {shell }}$ values $\left(\mathrm{F}^{14} \mathrm{C}_{\text {wholeshell }}\right)$ analysis than for either apertures or apices individually. This is likely to be due to the similarity of the datasets amplifying the observed trend. It is also probable that this approach filters out a significant portion of the local noise reflected in $\mathrm{F}^{14} \mathrm{C}$ values at individual sites. The stronger correlations between $\mathrm{F}^{14} \mathrm{C}$ values and tree and shrub cover are almost certainly a reflection of the dietary preferences of $\mathrm{H}$. melanostoma, indicating that they prefer taller arboreal vegetation over grasses and low lying herbaceous vegetation. The availability of such vegetation would appear to be a key variable that moulds the radiocarbon ecology of $H$. melanostoma in the study region where the vegetation is largely limited by grazing pressure since rainfall levels are always sufficient to support trees. Therefore radiocarbon ecology is responding to grazing pressure from domesticated animals and does not reflect a truly natural situation. This conforms well to existing research (e.g. Stott 2002) and could be an important influence if dating shells of this species found in association with Neolithic or later archaeological material where grazing of the local landscape would have been possible.

Figure 5. [a]Relationship between $\mathrm{F}^{14} \mathrm{C}_{\text {wholeshell }}$ and total vegetation cover. [b] Relationship between $\mathrm{F}^{14} \mathrm{C}_{\text {wholeshell }}$ and arboreal vegetation cover.

These findings also strongly support the hypothesis raised in other studies (e.g. Pigati et al., 2010) that calcium availability could be a contributory factor to the incorporation of old carbon into the diet. In almost all the sites, limestone availability was observed to be essentially inversely proportional to vegetation cover; so the positive trend between vegetation and higher $\mathrm{F}^{14} \mathrm{C}$ values is also a negative trend between limestone availability and 
lower $\mathrm{F}^{14} \mathrm{C}$ values. The most striking example of this is at Apollonia which has very poor vegetation cover, and $\mathrm{F}^{14} \mathrm{C}$ values for apices and apertures that are correspondingly much lower (Table 5). It may be, however, that this is a function not of limestone availability but of vegetation availability, which enforces grazing of endolithic algae, with an associated old carbon uptake from the limestone.

Figure 6. [a] Measured against predicted enrichment $\delta^{13} \mathrm{C}$ across the study area. Dashed line represents the line of best fit. [b] $\delta^{13} \mathrm{C}$ enrichment and depletion against arboreal cover across the study area.

Previous study has demonstrated that $H$. melanostoma in the sample region have a diet of C3 vegetation (Prendergast et al.,2014, 2015). As part of that study a modelling exercise calculating the dietary $\delta^{13} \mathrm{C}$ values for $H$. melanostoma if their diet was $100 \%$ vegetation was carried out. The results of this exercise together with the ${ }^{14} \mathrm{C}$ age offset are included in Table 6. The measured $\delta^{13}$ Cshell values, when compared with their modelled values, show both a significant observable trend in measured versus predicted $\delta^{13} \mathrm{C}$ enrichment in $H$. melanostoma shells (Figure 6 [a]) across the study areas (Table S1). Measured Samples from the Haua Fteah are mostly within the margin of error $( \pm 1 \%$ ) when compared. However samples, from other sites have much greater variation. There is a significant, positive relationship, with a moderate correlation between $\delta^{13} \mathrm{C}_{\text {shell }}$ enrichment/depletion and arboreal vegetation cover (Figure $6[\mathrm{~b}]$ ). Further comparison of $\delta^{13} \mathrm{C}_{\text {shell }}$ variations against other potential variables (Table S1) found that there were no significant trends across the sites sampled and no significant observable relationship between $\delta^{13} \mathrm{C}_{\text {shell }}$ and $\mathrm{F}^{14} \mathrm{C}_{\text {wholeshell }}$ values when compared directly across sampled sites (Table S1).

These findings are not surprising from an ecological or stable isotope perspective since there is a large body of past work that has found that the $\delta^{13} \mathrm{C}$ of land snail shells has a strong relationship with diet (e.g. Stott, 2002; Metref et al., 2003; Colonese et al., 2013; 2014; Yanes et al., 2008; 2014). The changes in enrichment and depletion and their correlation towards $\mathrm{F}^{14} \mathrm{C}$ values is interesting for ${ }^{14} \mathrm{C}$ dating and the issue of 'old carbon'. Sites which present the lowest $\mathrm{F}^{14} \mathrm{C}_{\text {shell }}$ values e.g. Apollonia, Shahat (Table 6) also present the most substantial enrichment in $\delta^{13} \mathrm{C}(>2 \%)$ values compared with what would be expected if their diet was entirely vegetation. The Haua Fteah which has good vegetation cover, and higher $\mathrm{F}^{14} \mathrm{C}$ values has less enrichment and are in some cases marginal depletion of $\delta^{13} \mathrm{C}$ values $( \pm 1 \%$ ). The trend shown in Figure $6[\mathrm{~b}]$ suggests that the magnitude of enrichment of samples may specifically relate to the availability of suitable dietary vegetation at sample sites, e.g. Ceratonia siliqua or Pistacia lentiscus. Areas lacking in arboreal vegetation in north eastern Libya also tend to have more significant outcroppings of limestone which would account for lower $\mathrm{F}^{14} \mathrm{C}$ values for samples from those regions as $H$. melanostoma could change its diet to compensate for the lack of vegetation. When considering the suitability of a species such as $\mathrm{H}$. melanostoma for ${ }^{14} \mathrm{C}$ dating this demonstrates the impact of dietary pressure on the $\mathrm{F}^{14} \mathrm{C}$ value of the shell very clearly in a way that was not picked up by direct comparison of the $\delta^{13} \mathrm{C}$ and $\mathrm{F}^{14} \mathrm{C}$ values. This relationship suggests that such a modelling exercise could be a useful tool in the future to flag specimens that may have an old carbon effect without directly dating ${ }^{14} \mathrm{C}$ dating a sample.

Relationships between $\mathrm{F}^{14} \mathrm{C}_{\text {shell }}$ and $\mathrm{F}^{14} \mathrm{C}_{\text {diet }}$ 
The relationship between $\mathrm{F}^{14} \mathrm{C}_{\text {shell }}$ and $\mathrm{F}^{14} \mathrm{C}_{\text {diet }}$ was also investigated for $\mathrm{H}$. melanostoma. There is only a slight correlation between changing $\mathrm{F}^{14} \mathrm{C}$ dietary values and $\mathrm{F}^{14} \mathrm{C}$ shell values (Table 3). This is broadly expected, as there is considerable variation within individual sample sites in $\mathrm{F}^{14} \mathrm{C}_{\text {shell }}$ and the sample size is not particularly large for some locations. In order to further compare $\mathrm{F}^{14} \mathrm{C}$ shell and $\mathrm{F}^{14} \mathrm{C}$ diet, age corrected ${ }^{14} \mathrm{C}$ (Figure 7) values were calculated, and the proportion of old carbon in the diet derived following the methods set out in Pigati et al., (2010) after Stuiver and Polach (1977) to facilitate easier comparison to previous studies.

Figure 7. $\mathrm{F}^{14} \mathrm{C}_{\text {shell }}$ and $\mathrm{F}^{14} \mathrm{C}_{\text {diet }}$ plotted as age corrected $\Delta^{14} \mathrm{C}$, demonstrating the variation and regional clustering of the old carbon effect for $\mathrm{H}$. melanostoma in the study region.

Findings imply that most specimens are incorporating a proportion of old carbon into their diets as a matter of course. What is significant is that there is a clear delineation that sits well with the earlier observations about vegetation availability and calcium dependency as modulating factors for shell carbonate composition. While the total range of values measured (Table 5) is large; (UBA 18082) $109 \pm 38{ }^{14} \mathrm{C}$ yrs to (UBA 21758) $2001 \pm 43{ }^{14} \mathrm{C}$ yrs with a weighted mean of $659 \pm 76{ }^{14} \mathrm{C}$ yrs, the majority of samples from non-urbanized sample locations have only a small old carbon effect with a weighted mean of $476 \pm 48{ }^{14} \mathrm{C}$ yrs which approximately relates to between $1-9 \%$ of their dietary $\mathrm{F}^{14} \mathrm{C}$ coming from nonorganic carbonate sources (Table 6) where this has been measured. The clear exceptions are samples from Apollonia and a single sample from Shahat; the urbanized sample locations manifest old carbon effects of $>1000{ }^{14} \mathrm{C}$ yrs and skew the averages accordingly. These more extreme carbonate environments are most likely to represent the modern extremities of the old carbon effect on $\mathrm{H}$. melanostoma. Such environments are highly unlikely to impact archaeological ages significantly since palynological evidence (Hunt et al., 2015; Simpson 2016) shows relatively stable vegetation cover in the region throughout the later Quaternary.

\section{Conclusions}

The ecological observations from all the sampled sites suggest that $H$. melanostoma has a very homogenous radiocarbon ecology in its natural habitats. There is a similar level of variation within $\mathrm{F}^{14} \mathrm{C}$ values across the majority of sample sites within the study area. Only in localities with drastically anthropogenically-altered habitats (Apollonia, Shahat) does $H$. melanostoma exhibit $\mathrm{F}^{14} \mathrm{C}$ values that are significantly distant from values observed at less impacted sites. This significant deviation from predicted levels of $\mathrm{F}^{14} \mathrm{C}$ for a species that preferentially consumes fresh, leafy vegetation is attributed to both the lack of choice vegetation and the influence of anthropogenic factors upon available vegetation (e.g. cement works, air pollution). These issues are unlikely to be significant in an archaeological context prior to the Roman Period and therefore these two localities may be regarded as clear outliers. It is significant that $\mathrm{F}^{14} \mathrm{C}$ values of apices are consistently lower than apertures across all sample sites. The scatter of $\mathrm{F}^{14} \mathrm{C}$ values for shell apertures, the most widely comparable $\mathrm{F}^{14} \mathrm{C}$ dataset, is very constrained. There is also a demonstrable trend of enrichment of $\delta^{13} \mathrm{C}$ at coastal and urbanized sample sites, decreasing availability of choice vegetation such as Ceratonia siliqua and Pistacia lentiscus and lower $\mathrm{F}^{14} \mathrm{C}$ values. This may suggest that enrichment in $\delta^{13} \mathrm{C}$ is a proxy indicator for the old carbon effect on $H$. melanostoma under certain circumstances. 
The most significant of these ecological observations are the very similar, and thus predictable differences between apertures and apices at all the sites and the predictable behaviour of old carbon incorporation. Both of which appear to be heavily modulated by the availability of choice vegetation such as Ceratonia siliqua and Pistacia lentiscus. The scale of differences between apertures and apices are very similar despite the distance between the sample sites, some variation in numbers of growth seasons and size of specimens. This suggests that the radiocarbon ecology of juvenile $H$. melanostoma may differ from that of adults where incorporation of carbonates is concerned. The lack of a significant difference between adult and juvenile $\delta^{13} \mathrm{C}$, even taking into considering the small number of samples involved $(n=5)$, opens up the possibility that the factor causing this variation is not vegetation availability. The investigation of modern $\mathrm{H}$. melanostoma further suggests weaknesses within the existing methods used in the radiocarbon dating of land molluscs, particularly the use of $\delta^{13} \mathrm{C}$ to estimate the impact of the 'limestone effect' within mollusc shells. In this instance this was found to over-emphasise the signature of dietary vegetation.

The similarity of the relationships between $\mathrm{F}^{14} \mathrm{C}$ values of shell apices and apertures to total vegetation cover suggests that both juvenile and adult $H$. melanostoma consume the same dietary vegetation, and that both are equally affected by this variable. Thus the increased $\mathrm{F}^{14} \mathrm{C}$ values of $\mathrm{H}$. melanostoma apices should originate in the non-organic carbonate component of diet and has the largest impact on the $\mathrm{F}^{14} \mathrm{C}$ values of the apices which is the longest growing part of the animal. It may also relate to subtle differences in vital effects due to differing fractionation chemistry between adult and juvenile animals, although only a limited number of juvenile snails were available to test this.

This is further supported by a marked increase in 'age' difference between the $\mathrm{F}^{14} \mathrm{C}$ of apices and apertures in Apollonia and those from the Gebel Akhdar. The landscape around Apollonia is limestone-dominated and has poor vegetation availability, whereas the Gebel Akhdar is comparatively well vegetated with much less outcropping limestone. This reinforces the conclusion that the significantly decreased $\mathrm{F}^{14} \mathrm{C}$ values at Apollonia are probably an extreme response to dietary pressure. It therefore seems reasonable to infer that dietary calcium availability could be the controlling factor for the incorporation of limestone into the diet of $\mathrm{H}$. melanostoma. The difference in the $\mathrm{F}^{14} \mathrm{C}$ values could be an indicator that juveniles simply consume more calcium carbonate than adults in order to construct their shells quickly during their first season of growth. There is much scope for further work on this hypothesis. Moreover many of the findings observed for $H$. melanostoma should also be observable for other species with similar ecological behaviour and should therefore be replicable for other taxa, elsewhere in the Mediterranean and further afield.

This study demonstrates that, in circumstances where there is a relatively complete vegetation cover including at least some trees and shrubs, the radiocarbon ecology of $H$. melanostoma is stable and predictable. The observed instabilities in the radiocarbon ecology of this species in Cyrenaica can all be attributed to the results of intense human activity which would not have been present before the Roman Period. Therefore this study opens up the use of $H$. melanostoma and species with similar ecological behaviour for radiocarbon dating of archaeological and geological deposits, with the use of a suitable offset to correct for the predictable effects of diet observed here.

\section{Acknowledgements}


We thank the Department of Antiquities of Libya in Tripoli and in Shahat for permissions and continued support from the inception of the project. We acknowledge the financial support of the Society for Libyan Studies, the Leakey Foundation, the University of Cambridge, and the European Research Council (ERC Advanced Investigator Grant 230421 to Graeme Barker). We thank our many Libyan and European colleagues for help, support and discussion over several field seasons. We thank the staff of the ${ }^{14} \mathrm{CHRONO}$ Centre, Queen's University Belfast including Stephen Hoper, Jim McDonald, Ron Reimer, Julia Simpson and Michelle Thompson for their expertise and advice. We also are indebted to constructive comments by Jeff Pigati and an anonymous reviewer.

\section{Bibliography}

Anketell JM, Ghellali SM, Gilbertson DD, Hunt CO. 1995. Quaternary wadi and floodplain sequences of Tripolitania, northwest Libya: a synthesis of their stratigraphic relationships, and their implications for landscape evolution. In Woodward JC, Macklin MG, \& Lewin J, (eds.) Mediterranean Quaternary River Environments. Rotterdam: Balkema, 231-244.

Augusto L, De Schriver A, Vesterdal L, Smolander A, Prescott C, Ranger J. 2015. Influences of evergreen gymnosperm and deciduous angiosperm tree species on the functioning of temperate and boreal forests. Biological Reviews 90(2): 444-466.

Balakrishnan M, Yapp CJ. 2004. Flux balance models for the oxygen and carbon isotope compositions of land snail shells. Geochimica et Cosmochimica Acta 68: 2007-2024.

Baldini LM, Walker SE, Bruce R, Baldini JUL, Crowe DE. 2007. Isotope ecology of the modern land snails Cerion, San Salvador, Bahamas: preliminary advances toward establishing a lowlatitude island palaeoenvironmental proxy. Palaios, 22: 174-187.

Barker G, Hunt CO, Reynolds T. 2007. The Haua Fteah, Cyrenaica (Northeast Libya): renewed investigations of the cave and its landscape. Libyan Studies 38, 2-22.

Barker G, Basell L, Brooks I, Burn L, Cartwright C, Cole F, Davison J, Farr L, Grun R, Hamilton R, Hunt, C, Inglis R, Jacobs Z, Leitch V, Morales J, Morley I, Morley M, Pawley S, Stimpson C, Twati M, Van der Veen M. 2008. The Cyrenaican Prehistory Project 2008: the second season of investigations of the Haua Fteah cave and its landscape, and further results from the initial 2007 fieldwork. Libyan Studies 39: 175-221.

Barker G, Antoniadou A, Armitage SJ, Brooks I, Candy I, Connell K, Douka K, Farr L, Hill E, Hunt CO, Inglis R, Jones S, Lane C, Lucarini G, Meneely J, Morales J, Mutri G, Prendergast AL, Rabett R, Reade H, Reynolds T, Russell N, Simpson D, Smith B, Stimpson C, Twati M, White K. 2010. The Cyrenaican Prehistory Project 2010: The fourth season of investigations of the Haua Fteah cave and its landscape, and further results from the 2007-2009 fieldwork. Libyan Studies 41: 63-88.

Barker G, Bennett P, Farr L, Hill E, Hunt CO, Lucarini G, Morales J, Mutri G, Prendergast AL, Pryor A, Rabett R, Reynolds T, Spry-Marques P, Twati M. 2012. The Cyrenaican Prehistory Project 2012: The fifth season of investigation of the Haua Fteah cave. Libyan Studies 43: 122. 
Bevington PR. 1969. Data reduction and error analysis for the physical sciences. New York, McGraw-Hill Inc.

Brandt RA. 1959. Die Helicellinae der Cyrenaika. Archiv für Molluskenkunde 88 : 81-150.

Colonese AC, Zanchetta G, Perlès C, Drysdale RN, Manganelli G, Baneschi I, Dotsika E, Valladas H. 2013. Deciphering late Quaternary land snail shell $\delta^{18} \mathrm{O}$ and $\delta^{13} \mathrm{C}$ from Franchthi Cave (Argolid, Greece). Quaternary Research 80: 66-75. http://dx.doi.org/10.1016/j.yqres.2013.03.006

Colonese AC, Zanchetta G, Fallick AE, Manganelli G, Lo Cascio P, Haussman N, Baneschi I, Regattieri E. 2014. Oxygen and carbon isotopic composition of modern terrestrial gastropod shells from Lipari Island, Aeolian Archipelago (Sicily). Palaeogeography, Palaeoclimatology, Palaeoecology 394: 119-127. http://dx.doi.org/10.1016/j.palaeo.2013.12.003

Draparnaud, JPR. 1801. (an IX) Tableau des Mollusques terrestres et fluviatiles de la France. Montpellier et Paris 116.

De Jorge FB, Haeser PE. 1968. Further Biochemical studies on the snail Strophocheilus oblongus musculus Becquaert. Comparative Biochemistry and Physiology 26: 627-637.

El-Hawat AS, Abdulsamad EO, 2004. The geology of Cyrenaica: A field seminar: 3rd Sedimentary Basins of Libya Symposium. Geology of East Libya, Benghazi, November 21-23, 2004, Field guide, $130 \mathrm{p}$.

Farr L, Lane R, Abdulazeez F, Bennett P, Holman J, Marasi A, Prendergast A, Al-Zweyi M, Barker G. 2014. The Cyrenaican Prehistory project 2013: The seventh season of excavations in the Haua Fteah. Libyan Studies 45: 163-173.

Goodfriend GA. 1987. Radiocarbon age anomalies in shell carbonate of land snails from semi-arid areas. Radiocarbon 29: 159-167.

Goodfriend GA, Ellis GL. 2002. Stable carbon and oxygen isotopic variations in modern Rabdotus land snail shells in the southern Great Plains, USA, and their relation to environment. Geochimica et Cosmochimica Acta 66: 1987-2002.

Goodfriend GA, Hood DG. 1983. Carbon isotope analysis of land snail shells: implications for carbon sources and radiocarbon dating. Radiocarbon 25: 810-830.

Hegazy AK, Boulos L, Kabiel HF, Sharashy OS. 2011. Vegetation and species altitudinal distribution in al-Jabal al-Akhdar landscape, Libya. Pakistan Journal of Botany 43(4): 18851898.

Hill E. 2010. Ecological sampling for land snails outside the Haua Fteah cave. In Barker G, Antoniadou A, Armitage SJ, Brooks I, Candy I, Connell K, Douka K, Farr L, Hill E, Hunt CO, Inglis R, Jones S, Lane C, Lucarini G, Meneely J, Morales J, Mutri G, Prendergast AL, Rabett R, Reade H, Reynolds T, Russell N, Simpson D, Smith B, Stimpson C, Twati M, White K. 2010. The Cyrenaican Prehistory Project 2010: The fourth season of investigations of the Haua Fteah cave and its landscape, and further results from the 2007-2009 fieldwork. Libyan Studies 41: 83-84.

Hill EA. 2015. The Radiocarbon dating of Terrestrial Molluscs in North East Libya. Unpublished PhD Thesis, Queens University Belfast. 
Hunt CO, Garrard AN. 2013. The Late Palaeolithic-Geological Context. In Garrard AN. \& Byrd BF. (eds.) Beyond the Fertile Crescent. Late Palaeolithic and Neolithic Communities of the Jordanian Steppe: The Azraq Basin Project, Vol. 1. Oxford, Oxbow: Levant Supplementary Series 13: 54-135.

Hunt CO, Gilbertson DD, Hill EA, Simpson D. 2015. Sedimentation, re-sedimentation and chronologies in archaeologically important caves: problems and prospects. Journal of Archaeological Science 56: 109-116.

Hunt CO, Gilbertson DD. Donohue RE. 1992. Palaeobiological evidence for agricultural soil erosion in the Montagnola Senese, Italy. In Bell M, Boardman J. (eds.) Past and Present Soil Erosion: Archaeological and Geographical Perspectives. Oxford, Oxbow Monographs, 22: 163-174.

Hua Q, Barbetti M, Rakowski AZ. 2013. Atmospheric radiocarbon for the period 1950-2010. Radiocarbon 55.

Kerney MP, Cameron RA. Jungbluth JH. 1983. Die Landschnecken Nord-Und Mitteleuropas. Wiley-Blackwell, New Jersey.

Keaveney EM, and Reimer P J. 2012. Understanding the variability in freshwater radiocarbon reservoir offsets: a cautionary tale: Journal of Archaeological Science 39 (5):1306-1316.

Levin I, Kromer B, Hammer S, 2013. Atmospheric $\Delta^{14} \mathrm{CO}_{2}$ trend in Western European background air from 2000 to 2012. Tellus B 201365.

McConnaughey TA, Gillikin DP. 2008. Carbon isotopes in mollusk shell carbonates. GeoMarine Letters 28: 287-299.

Magaritz M, Heller J, Volokita M. 1981. Land-air boundary environment as recorded by the ${ }^{18} \mathrm{O} /{ }^{16} \mathrm{O}$ and ${ }^{13} \mathrm{C} /{ }^{12} \mathrm{C}$ isotope ratios in the shells of land snails. Earth and Planetary Science Letters 52: 101-6.

Metref S, Rousseau DD, Bentaleb I, Labonne M, Vianey-Liaud M. 2003. Study of the diet effect on $\delta^{13} \mathrm{C}$ of shell carbonate of the land snail Helix aspersa in experimental conditions. Earth and Planetary Science Letters 211: 381-393.

Millard AR. 2014. Conventions for Reporting Radiocarbon Determinations: Radiocarbon 56 : 555-559.

Pfleger V. 1984. Schnecken und Muscheln Europas. Land und Sußwasserarten. Kosmos, Stuttgart.

Pigati JS, Quade J, Shahanan TM, Haynes CV Jr. 2004. Radiocarbon dating of minute gastropods and new constraints on the timing of late Quaternary spring discharge deposits in southern Arizona, USA. Palaeogeography Palaeoclimatology Palaeoecology 204: 33-45.

Pigati JS, Rech JA, Nekola JC. 2010. Radiocarbon dating of small terrestrial gastropod shells in North America. Quaternary Geochronology 5:519-532. 
Prendergast, A. 2013. Late Pleistocene to Holocene human-environment interaction in the south eastern Mediterranean: Stable isotope analysis of mollusc shells from Haua Fteah, Libya and Ksar Akil, Lebanon. Unpublished PhD Thesis, University of Cambridge.

Prendergast AL. Stevens RE. 2014. Molluscs (isotopes): analyses in environmental archaeology. The Encyclopaedia of Global Archaeology pp. 5010-5019. Springer, Berlin.

Prendergast AL, Stevens RE, Barker GW, O'Connell TC. 2015. Oxygen isotope signatures from land snail (Helix melanostoma) shells and body fluid: proxies for reconstructing Mediterranean and North African rainfall. Chemical Geology 409: 87-98.

Prendergast AL, Stevens RE, Hill EA, Barker GW, Hunt C, O'Connell TC. 2014. Carbon isotope signatures from land snail shells: Implications for palaeovegetation reconstruction in the eastern Mediterranean. Quaternary International. 01/2015; DOI:http://dx.doi.org/10.1016/j.quaint.2014.12.053.

Quarta G, Romaniello L, D’Elia M, Mastronuzzi G, Calcagnile L. 2007. Radiocarbon age anomalies in pre- and post-bomb land snails from the coastal Mediterranean basin. Radiocarbon 49: 817-826.

Rabett R, Farr LJ, Hill E, Hunt CO, Lane R, Moseley H, Stimpson C, Barker G. 2012. The Cyrenaica Prehistory Project 2012: The sixth season of excavations at the Haua Fteah cave. Libyan Studies 44: 113-125.

Reimer P, Baillie M, Bard E, Bayliss A, Beck J, Blackwell P, Ramsey CB, Buck C, Burr, G, Edwards, R, Friedrich $M$, Grootes $P$, Guilderson $T$, Hajdas I, Heaton $T$, Hogg $A$, Hughen $K$, Kaiser K, Kromer B, McCormac F, Manning S, Reimer R, Richards D, Southon J, Talamo S, Turney C, van der Plicht J, Weyhenmeyer C. 2009. IntCal09 and Marine09 radiocarbon age calibration curves, 0-50,000 years cal B.P. Radiocarbon 51: 1111-1150.

Romaniello L, Quarta G, Mastronuzzi G, D’Elia M, Calcagnile L. 2008. ${ }^{14} \mathrm{C}$ age anomalies in modern land snails shell carbonate from Southern Italy. Quaternary Geochronology 3: 6875.

Rakovan MT, Rech JA, Pigati JS, Nekola JC, Wiles GC. 2013. An evaluation of Mesodon and other larger terrestrial gastropod shells for dating late Holocene and historic alluvium in the Midwestern USA. Geomorphology 193: 47-56.

Şen Z, Eljadid AG. 1999. Rainfall distribution function for Libya and rainfall prediction, Hydrological Sciences Journal 44(5): 665-680.

Simpson D. 2016. The Palynology of the Haua Fteah, Libya. Unpublished PhD Thesis, Queen's University Belfast.

Soulet G, Skinner LC, Beaupre SR, Galy V. 2016. A Note on Reporting of Reservoir ${ }^{14} \mathrm{C}$ Disequilibria and Age Offsets. Radiocarbon 58: 205-211.

Slota PJ, Jr, Jull AJT, Linick TW, Toolin L. 1987. Preparation of small samples for ${ }^{14} \mathrm{C}$ accelerator targets by catalytic reduction of CO. Radiocarbon 29: 303-306.

Stott LD. 2002. The influence of diet on the $\delta^{13} \mathrm{C}$ of shell carbon in the pulmonate snail Helix aspersa. Earth and Planetary Science Letters 195: 249-259. 
Stuiver M, Polach HA. 1977. Discussion: reporting of 14 C data. Radiocarbon 19: 355-363.

Tamers MA. 1970. Validity of radiocarbon dates on terrestrial snail shells. American Antiquity 35: 94-100.

Vogel JS, Southon, JR, Nelson DE. 1987. Catalyst and binder effects in the use of filamentous graphite for AMS. Nuclear Instruments and Methods in Physics Research B 29(1-2):50-6.

Xu B, Gu Z, Han J, Liu Z, Pei Y, Lu Y, Wu N, Chen Y. 2010. Radiocarbon and stable isotope analyses of land snails from the Chinese loess plateau: Environmental and chronological implications. Radiocarbon 52: 149-156.

Xu B, Gu Z, Han J, Hao Q, Lu Y, Wang L, Wu N, Peng Y. 2011. Radiocarbon age anomalies of land snail shells in the Chinese Loess Plateau. Quaternary Geochronology 6: 383-389.

Yanes Y, Delgado A, Castillo C, Alonso MR, Ibanez M, De la Nuez J, Kowalewski M. 2008. Stable isotope $(\delta 180, \delta 13 C$, and $\delta D)$ signatures of recent terrestrial communities from a low-latitude, oceanic setting: Endemic land snails, plants, rain, and carbonate sediments from the eastern Canary Islands. Chemical Geology 249: 377-392.

Yanes Y, Izeta AD, Cattaneo R, Costa T, Gordillo S, 2014. Holocene ( 4.5-1.7 cal. Kyr BP) Palaeoenvironmental conditions in central Argentina inferred from entire shell and intrashell stable isotope composition of terrestrial gastropods. Holocene 24(10): 1193-1205. 